\title{
INTERNATIONAL MOBILITY OF A COMMUNITY OF STUDENTS FROM THE UNIVERDADE DO ALGARVE
}

\section{Margarida Viegas \\ mmviegas@ualg.pt}

Adjunct Professor of Applied Quantitative Methods at the Universidade do Algarve's School of Management, Hospitality and Tourism (ESGHT-UAlg, Portugal). She holds a degree in Engineering of Decision Systems from ISMA-COCITE and a post-graduate in Financial Management from UAlg and in Strategic Direction and e-Business from the Universidad de Huelva. She also has a master's in Statistics and Information Management from ISEGIUniversidade Nova de Lisboa and a PhD in Management and Economics of Small and Medium Enterprises from the Universidad de Huelva, which distinguished her thesis with the

Extraordinary PhD Award.

\section{Rita Baleiro}

rbaleiro@ualg.pt

$\mathrm{PhD}$ and master's in Anglo-Portuguese Studies by the Faculty of Social Sciences and Humanities of the Universidade Nova de Lisboa (UNL, Portugal). She is an Adjunct Professor at the

Universidade do Algarve's School of Management, Hospitality and Tourism. She is an integrated member of the Centre for Comparative Studies of the Faculty of Arts at the Universidade de

Lisboa, collaborator of the Centre for English, Translation and Anglo-Portuguese Studies at UNL and member of the Research Group of Tourism, Space and Urbanities of the Universidade Federal do Rio de Janeiro. She is co-editor of the magazine Dos Algarves: A Multidisciplinar e-Journal

since 2007.

\section{Abstract}

This study compiles data on the mobility of a group of Portuguese public higher education students. It aims to understand how these young people are seeing their professional future and the hypothesis of international labour and academic mobility in a period of economic and social crisis. Based on data from a survey applied to 425 students of the Universidade do Algarve in 2016, their predisposition for mobility is analysed according to their professional perspectives, demographic characteristics and language skills. The results show that most of the respondents $(69.6 \%)$ consider the possibility of working abroad and that this intention is motivated by the disbelief of reaching, in Portugal, work that provides stability and security, good remuneration conditions and social prestige. The possibility of an international academic experience, considered by $60.7 \%$ of the students, is not associated with the benevolent selfassessment of language skills. However, in the case of labour mobility, it was seen that this predisposition is greater amongst those who express greater confidence in their English skills.

\section{Keywords}

International mobility; students; Universidade do Algarve; economic crisis; Portugal

\section{How to cite this article}

Viegas, Margarida; Baleiro, Rita (2019). "International mobility of a community of students from the Universidade do Algarve". JANUS.NET e-journal of International Relations, Vol. 10, N. ${ }^{\circ}$ 1, May-October 2019. Consulted [online] on the date of the last visit, https://doi.org/10.26619/1647-7251.10.1.9

Article received on January 16, 2018 and accepted for publication on February 22, 2019

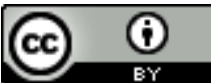




\title{
INTERNATIONAL MOBILITY OF A COMMUNITY OF STUDENTS FROM THE UNIVERDADE DO ALGARVE ${ }^{1}$
}

\author{
Margarida Viegas \\ Rita Baleiro
}

\section{The economic and financial crisis of 2008 and the international mobility of Portuguese university students}

At the beginning of the first decade of the $21^{\text {st }}$ century, when the Portuguese pondered the issue of emigration in Portugal, the most probable conclusion was that this type of migratory movement had reached its peak in the 1950s and 1960s, and that in the beginning of the $21^{\text {st }}$ century the focus of attention would be precisely the opposite movement: immigration. In fact, as Jorge Malheiros points out, between the beginning of the 1990s and the middle of the 2000s, for both the political class and the academia, Portuguese emigration had become almost invisible regarding migratory phenomena (2011: 133). It was because Portugal benefited from the status of an economically prosperous and stable country, where immigration ${ }^{2}$ was more aspired than emigration.

However, the crisis of 2008 changed this situation. In 2016, when this study was carried out, Portugal was still experiencing the effects. In fact, the bankruptcy of the investment bank Lehman Brothers on September 15, 2008, triggered the domino effect that led to the collapse of the speculative bubble in the real estate market, boosted by the huge increase in bank credit and the creation and application of new financial instruments. As a consequence, the credit suspension caused a sharp crash in industrial production and international trade. In Portugal, these effects along with austerity policies - rising taxes, prices, freezing of wages, etc. from 2010 have led to the erosion of employment opportunities for all, with particularly harmful impacts on the youth, which corresponds to the ones who were starting professional paths (see Carneiro, Portugal \& Varejão, 2014).

Between 2008 and 2013, the general unemployment rate in Portugal almost doubled, from $7.6 \%$ to $16.2 \%$ (see Table 1), whilst in the age group "under the age of 25 years" it changed from $16.7 \%$ to $38.1 \%$ In 2016 , the year when this study was conducted, the same database estimated that the youth unemployment rate (under 25 years' old) was

The translation of this article was funded by national funds through FCT - Fundação para a Ciência e a Tecnologia - as part of OBSERVARE project with the reference UID/CPO/04155/2019, with the aim of publishing Janus.net. Text translated by Thomas Rickard.

2 About the immigration movement to Portugal, see J.M. Malheiros \& A. Esteves (2013). Diagnóstico da população imigrante em Portugal: Desafios e potencialidades. Lisboa: Alto Comissariado para a Imigração e Diálogo Intercultural. 
$28.0 \%$. Therefore, there was a decrease compared to previous years, as it happened in the euro area, where the unemployment rate changed from $22.2 \%$, in 2015 , to $20.7 \%$, in 2016.

Table 1. Unemployment rate in Portugal: Total and by age group (\%)

\begin{tabular}{|c|c|c|c|c|}
\hline \multirow{2}{*}{ Years } & \multicolumn{4}{|c|}{ Age Groups } \\
\hline & Total & $<25$ & $25-54$ & $55-64$ \\
\hline 2004 & 6.6 & 15.4 & 6.0 & 5.5 \\
\hline 2005 & 7.6 & 16.2 & 7.2 & 6.1 \\
\hline 2006 & 7.6 & 16.5 & 7.3 & 6.3 \\
\hline 2007 & 8.0 & 16.7 & 7.8 & 6.5 \\
\hline 2008 & 7.6 & 16.7 & 7.2 & 6.6 \\
\hline 2009 & 9.4 & 20.3 & 9.2 & 7.6 \\
\hline 2010 & 10.8 & 22.8 & 10.7 & 8.9 \\
\hline 2011 & 12.7 & 30.2 & 11.9 & 10.8 \\
\hline 2012 & 15.5 & 37.9 & 14.7 & 12.7 \\
\hline 2013 & 16.2 & 38.1 & 15.5 & 13.7 \\
\hline 2014 & 13.9 & 34.8 & 12.7 & 13.5 \\
\hline 2015 & 12.4 & 32.0 & 11.2 & 12.4 \\
\hline 2016 & 11.1 & 28.0 & 10.0 & 11.6 \\
\hline
\end{tabular}

Source: Pordata (last update in March 22, 2017).

Even when the general unemployment rate decreases, the youth unemployment remains high, in addition to the fact that most employment opportunities for young people correspond mainly to temporary jobs (Silva \& Abrantes, 2017: 1336). The investigations that analysed the Portuguese employability and the youth pointed out that, in addition to the high unemployment rates, there are increasing wage inequalities (Carmo, Cantante \& Alves, 2014) and much precariousness (Alves, Singer, Baptista \& Carmo, 2011). This latest study by the Observatório das Desigualdades (Observatory of Inequalities) also noted that precariousness is not confined to the labour issue and affects the multiple dimensions and sectors of the social life of the youth.

Within this national context, between 2010 and 2016, around 96,000 Portuguese emigrated each year - the peak was registered in 2014, with the departure of 134,624 Portuguese citizens. ${ }^{3}$ According to data collected on the website of the Observatório da Emigração (Observatory of Emigration), which cited data from the United Nations, in 2015 the percentage of Portuguese emigrants living in Europe was 62\%, whilst in 1990 it was $53 \%$. Besides this sudden and high number of emigrants, it should be noted, as Jorge Malheiros points out, that this migrant movement is distinct from that of the $1960 \mathrm{~s}$ and 1970s: (i) Europe is a diverse emigration space, since it is an area of free movement

3 See "Estimates of the total Portuguese emigrants, 2000-2015" at the Observatory of Emigration. Accessed on July 18, 2017. 


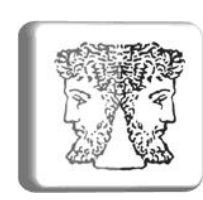

and (ii) "a substantial part of this emigration takes on a temporary and not a definitive logic, which is also favoured by the possibilities of free movement" (2011: 135).

As already mentioned, this investigation took place in 2016, the eighth year of the greatest financial crisis since the Great Depression of 1929 . The country was experiencing economic crisis and the consequences of austerity measures imposed by the triad of the International Monetary Fund, European Central Bank and European Commission. All these factors have had serious implications on the lives and life prospects of many young Portuguese graduates: discouragement, job insecurity and unemployment (Cairns, 2015: 10; Cairns, 2017: 340).

There are several studies that registered the impact of the economic crisis on the lives of young Europeans at the beginning of the $21^{\text {st }}$ century (see Cairns, 2017; Papadopoulos, 2014; Dietrich, 2013; Aassve, Cottini \& Vitali, 2013; Bell \& Blanchflower, 2011; Scarpetta, Sonnet \& Manfredi, 2010). During the economic crisis, the overall unemployment rate in Europe increased by 3.3\% between 2007 and 2013, whilst the youth unemployment increased further, reaching $7.3 \%$ in the 20-24 age group and 5.1 $\%$ for those between 25-29 years of age (see OECD, 2013). That is, on the Old Continent the percentage of young people (20-24 years) unemployed reached levels higher than double the overall percentage of unemployment. This trend has been observed in several European countries, such as the Republic of Ireland, Greece, Cyprus, Spain. Germany was the only exception as its youth unemployment rate (20-24 years) decreased by 3.3\% between 2007 and 2012 (i.e. from 9.8\% to 6.5\%) (see OECD, 2013). Despite the differential impact of the crisis, previous studies show that international labour mobility after graduation is one of the most frequent options in the vast majority of countries, even though it is transitory.

Mobility is understood here as the geographical movement between borders, for countries other than the one of origin, with a minimum stay of two weeks (Kmiotek-Meier, Carignani \& Vysotskaya, 2019: 32). At this point, it is also crucial to distinct between "mobility" and "emigration" as there has been a change in terminology in recent years and the first term is preferable to the second, according to King, Lulle, Morosanu and Williams (2016: 8). This change is due to the fact that mobility is a politically more neutral term whereas emigration has a long past and is seen in many countries as a threat (King \& Lulle, 2016: 30-31). Thus, emigration implies a displacement to a country where one stays for longer periods of time - sometimes even permanently - whilst mobility is characterised by a more transient movement. Engbersen and Snel (2013) suggest the term "liquid migration" to refer to this type of intra-frontier displacement in European Union, which currently has various forms: work trips, academic/professional internships, study programs, exchanges of various type, among others. King, Lulle, Morosanu and Williams (2016: 9) observed a tendency in Europe for the use of the term "mobility" when describing movements between European countries - since it is more suitable for the motto of "freedom of movement" - and the use of "emigration" to indicate displacements outside the European area.

At this point, it is also worth clarifying the term "youth". Like the other age categories childhood, middle age or old age - youth is a socially and culturally constructed category and not a concept defined chronologically, and there is no unanimity about it. In other words, youth/young is a plastic, contextual, situational and, above all, a relational concept as it is defined in relation to - or to the transition between - another age category (King, Lulle, Morosanu \& Williams, 2016: 9). 
According to Pordata ${ }^{4}$ data, the highest rate of youth mobility was registered in 2012, including people in the 15-19, 20-24 and 25-29 age groups. Amongst them, the highest number corresponds to the 25-29 age group, and there is a decreasing trend from 2012 onwards (see Table 2).

Table 2. Portuguese mobility numbers by age group (2008-2015)

\begin{tabular}{|c|c|c|c|c|c|c|c|c|c|c|c|c|}
\hline & Total & $15-19$ & $20-24$ & $25-29$ & $30-34$ & $35-39$ & $40-44$ & $45-49$ & $50-54$ & $55-59$ & $60-64$ & $65+$ \\
\hline 2008 & 20.357 & 1.251 & 4.393 & 5.377 & 3.124 & 1.512 & 868 & 237 & 7 & 0 & 0 & 0 \\
\hline 2009 & 16.899 & 1.039 & 3.649 & 4.465 & 2.593 & 1.256 & 720 & 196 & 6 & 0 & 0 & 0 \\
\hline 2010 & 23.760 & 1.460 & 5.127 & 6.276 & 3.644 & 1.765 & 1.013 & 277 & 8 & 0 & 0 & 0 \\
\hline 2011 & 43.998 & 3.277 & 6.237 & 6.097 & 5.075 & 3.952 & 3.044 & 3.032 & 1.520 & 611 & 118 & 553 \\
\hline 2012 & 51.958 & 4.378 & 10.563 & 11.022 & 7.184 & 5.383 & 3.753 & 3.505 & 1.579 & 990 & 248 & 510 \\
\hline 2013 & 53.786 & 2,775 & 9.722 & 8.917 & 6.303 & 5.821 & 5.499 & 4.898 & 3.047 & 1.774 & 942 & 1.827 \\
\hline 2014 & 49.572 & 2.661 & 8.776 & 8.122 & 5.596 & 5.250 & 5.159 & 4.588 & 3.040 & 1.723 & 964 & 1.776 \\
\hline 2015 & 40.377 & 2.705 & 7.266 & 8.146 & 5.601 & 4.189 & 3.652 & 3.147 & 1.878 & 1.048 & 290 & 356 \\
\hline
\end{tabular}

Source: Pordata (last update in October 28, 2016).

In the book Return to the future: The new emigration and the Portuguese society, researchers identify two trends: one of those moving to other European countries (the youngest and the less educated) and those moving outside Europe (the less young and more skilled). The same study shows that, generally, Angola, Mozambique, Brazil and the United Kingdom are the destination for the most qualified individuals, and that in 2015 the United Kingdom was the country where most Portuguese emigrated: 32,300 (see Observatory of Emigration). On the other hand, the flow to Angola and Mozambique is more appealing to less-young professionals and is closely associated with transfers of employees from Portuguese companies. The book also denies that Portugal has lost half a million people to emigration since the beginning of the crisis, as the media sometimes affirms (see Santos, 2016). In fact, although the INE counts 485,128 displacements between 2011 and 2014, many of them last less than one year - between 2011 and 2016 , this type of movement rose from $56 \%$ to $63 \%$. Despite this aspect as well as the return of some of those who had left, the truth is that during the financial and economic crisis an unprecedented number of recent graduates leaving Portugal was observed. It was in this context and before this evidence that this study was carried out.

The article is structured into four sections. In this first one, which also corresponds to the introduction, the European and Portuguese context during the economic and financial crisis in relation to the unemployment and emigration number was generally presented, since it was during this period that the survey was applied. In addition, the main studies that analysed the effects of the economic crisis on European youth were introduced and the concepts of mobility and youth were defined. In the second section, the objectives of the study, research design, data collection instrument, process and context of the survey application are described. Subsequently, the results are presented. In the last section,

4 Data verified according to the numbers made available by the Instituto Nacional de Estatística (INE) - the National Statistical Institute of Portugal. 


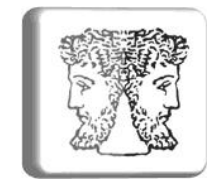

the main conclusions and limitations of this study are highlighted as well as the possibilities of future investigations.

\section{Methodology}

\subsection{Study objectives}

This study intends to analyse the perceptions of the students of the School of Management, Hospitality and Tourism of the Universidade do Algarve (ESGHT-UAlg) regarding their professional future and perspectives on international mobility. This school was chosen because it is the one with the highest number of students at this public university (approximately 2,000 students). Thus, the study objectives are:

$\Rightarrow$ to analyse the professional perspectives, both in general terms and in relation to the national labour market, and to identify in what aspects they differ;

$\Rightarrow$ to examine the relationship between the various professional aspects considered and the predisposition for international labour mobility;

$\Rightarrow$ to characterise the predisposition for international mobility, both labour and academic, according to demographic characteristics and language skills.

\subsection{Research design}

This research was based on an ex post facto and descriptive design, using a probing survey as a method of collecting primary data. The fourteen questions included in the questionnaire, resulting from bibliographic research and consultation of similar studies, are grouped into four sections: professional perspectives; international mobility (labour and academic); language skills and demographic characteristics (age, gender, course, year).

Regarding professional perspectives, two Likert-type scales are used to assess both the importance that respondents generally attribute to certain aspects of working life (1 not important to 5 - extremely important) and to the perspective of having a future work in Portugal ( 1 - very bad to 5 - very good). The aspects considered are: employment opportunities; stability and security; remuneration conditions; possibility of career ladder; good relationship with colleagues and superiors; flexible hours; work that safeguards health and well-being; work with social prestige.

In the section on international mobility, respondents indicated if they have studied or considered studying abroad (international academic mobility) as well as if they have considered the possibility of working abroad (international labour mobility). If so, they had to rank their three preferred countries; and, if not, they had to indicate the influence that the recent terrorist attacks in European cities could have on this decision (none, a little, much). They were also asked to: identify family members with emigration experience (current or past); associate a word with "emigration"; and express their level of agreement with the statement "Two years from now the crisis will have ended and the employment situation in Portugal will be better than today", (1 - strongly disagree to 5 completely agree).

In relation to language skills, respondents were asked to indicate the number of failures to curricular units of languages and the classification obtained in those they concluded. 
They should also self-assess their knowledge of English, German and Spanish (insufficient, sufficient, good or excellent) and indicate an English language certification exam.

\subsection{Data collection and sample characterisation}

As already mentioned, the target population was the students of the ESGHT-UAlg. This institution is located in Faro, the capital of the province of Algarve: the southernmost province of Portugal and the most touristic region of the country. The university, one of the fourteen Portuguese public universities, was created in 1979 and brings together two pre-existing institutions: the Universidade do Algarve (University of Algarve) and the Instituto Politécnico de Faro (Faro Polytechnic Institute).

The questionnaire was applied to a non-probabilistic sample of convenience to 425 students from the three years of the ESGHT-UAlg (Management, Tourism, Marketing and Hotel Management) degrees (see Table 3). The application was carried out in a classroom situation in two different moments: in January and June, 2016. The collected data were individually verified and analysed through the SPSS vs. 23 program.

Table 3. Distribution of students by degree and year of undergraduate degree

\begin{tabular}{|c|c|c|c|c|c|}
\hline \multirow{2}{*}{ Course } & \multicolumn{2}{|c|}{ Total } & \multicolumn{3}{c|}{ Students / Year } \\
\cline { 2 - 6 } & $\begin{array}{c}\text { Number of } \\
\text { students }\end{array}$ & $\%$ Students & 1 st & 2nd & 3rd \\
\hline Management & 143 & 33.6 & $33.3 \%$ & $26.92 \%$ & $44.71 \%$ \\
\hline Tourism & 121 & 28.5 & $31.43 \%$ & $33.08 \%$ & $14.12 \%$ \\
\hline Marketing & 72 & 16.9 & $13.81 \%$ & $21.54 \%$ & $17.65 \%$ \\
\hline Hotel Management & 89 & 20.9 & $21.43 \%$ & $18.46 \%$ & $23.53 \%$ \\
\hline
\end{tabular}

\section{Results presentation ${ }^{5}$}

\subsection{Characterisation of the respondents}

The average age of the students surveyed was 22 years, with no significant differences between the various courses (Table 4 ). For the first years, the average age for all courses is 21 years old; and for the second, it is 22 years old in Management and Tourism and 21 in Marketing and Hotel Management. There is no significant differences in both cases (Kruskall-Wallis tests with $\mathrm{p}=0.51$ and 0.50 , respectively).

5 All tests presented are performed with a significance level of $5 \%$. 
Table 4. Average age per course

\begin{tabular}{|c|c|c|c|}
\hline \multirow{2}{*}{ Course } & \multirow{2}{*}{ Average age } & \multicolumn{2}{|c|}{ Kruskall-Wallis } \\
\hline & & $x^{2}$ & $p$ \\
\hline Management & 22 & \multirow{4}{*}{6.13} & \multirow{4}{*}{0.11} \\
\hline Tourism & 22 & & \\
\hline Marketing & 21 & & \\
\hline Hotel Management & 21 & & \\
\hline
\end{tabular}

Regarding the third years, the students of Management have an average age above the global average and significantly higher than the ones of Tourism and Hotel Management (Table 5).

Table 5. Average age for 3rd year

\begin{tabular}{|l|c|c|c|c|}
\hline \multicolumn{1}{|c|}{$\begin{array}{c}\text { Course (3rd year) } \\
(\bar{X}=\mathbf{2 4})\end{array}$} & Average age & \multicolumn{2}{|c|}{ Kruskall-Wallis } & \multirow{2}{*}{ Fisher's LSD } \\
\cline { 2 - 2 } & 25 & $\mathrm{X} 2$ & $\mathrm{p}$ & \\
\hline Management & 22 & \multirow{2}{*}{9.96} & 0.02 & \multirow{2}{*}{ Gestão $\neq$ Tur; GH } \\
\hline Tourism & 24 & & \\
\hline Marketing & 23 & & & \\
\hline Hotel Management & & & \\
\hline
\end{tabular}

Although weak ( $\mathrm{V}$ of Cramer $=0.2$ ), there is an association between the gender of the students and the course attended (Chi-square $=17.68 ; p=0.001$ ), especially for Management as it is the only one to present a majority of male students. All the courses are mostly attended by female students, with the highest percentage in Tourism (see Table 6).

Table 6. Distribution of students by degree and gender

\begin{tabular}{|l|c|c|}
\hline \multicolumn{1}{|c|}{ Course } & Gender & \% \\
\hline \multirow{2}{*}{ Management } & Female & $45.5 \%$ \\
\hline \multirow{2}{*}{ Tourism } & Male & $54.5 \%$ \\
\cline { 2 - 3 } & Female & $69.2 \%$ \\
\hline \multirow{2}{*}{ Marketing } & Male & $30.8 \%$ \\
\cline { 2 - 3 } & Female & $65.3 \%$ \\
\hline \multirow{2}{*}{ Hotel Management } & Male & $34.7 \%$ \\
\cline { 2 - 3 } & Female & $52.8 \%$ \\
\cline { 2 - 3 } & Male & $47.2 \%$ \\
\hline
\end{tabular}




\subsection{Professional perspective and predisposition for international labour mobility}

In relation to their future professional life, the factors most valued by students - both in general terms and in each course - are employment opportunities and the possibility of career ladder, followed by stability and security, and fourthly the remuneration conditions. The same aspects, when evaluated from the perspective of professional life in Portugal, present significantly lower values. Amongst them, the best-classified ones are related to the good relationship with colleagues/superiors and the safeguard of health and well-being (Table 7).

Table 7. Valorisation of professional aspects

\begin{tabular}{|c|c|c|c|c|}
\hline \multirow{3}{*}{ Perspective of future professional life } & \multicolumn{2}{|c|}{ Average Values } & \multicolumn{2}{|c|}{ Test t paired samples } \\
\hline & \multirow{2}{*}{$\begin{array}{c}\text { General } \\
(4.41)\end{array}$} & \multirow{2}{*}{$\begin{array}{c}\text { Portugal } \\
(3.24)\end{array}$} & & \\
\hline & & & $\mathbf{t}$ & $\mathbf{p}$ \\
\hline Employment opportunities & 4.54 & 3.19 & 25.30 & 0.00 \\
\hline Stability and security & 4.29 & 3.30 & 17.44 & 0.00 \\
\hline Remuneration conditions & 4.21 & 2.97 & 20.49 & 0.00 \\
\hline Possibility of career ladder & 4.43 & 3.13 & 23.12 & 0.00 \\
\hline Good relationship with colleagues and superiors & 4.19 & 3.70 & 10.93 & 0.00 \\
\hline Flexible hours & 3.69 & 3.17 & 10.61 & 0.00 \\
\hline Safeguard of health and well-being & 4.17 & 3.49 & 13.68 & 0.00 \\
\hline Social prestige & 3.30 & 2.96 & 6.99 & 0.00 \\
\hline
\end{tabular}

When evaluated from the perspective of the professional future, none of these aspects are associated with the predisposition for international labour mobility as well as in relation to a professional future in Portugal. In this perspective, there is a dependence between this predisposition and the evaluation of the aspects "Stability and security", "Remuneration conditions" and "Social prestige" (respectively: $X^{2}=10.81, p=0.03 ; X^{2}$ $\left.=14.64, p=0.06 ; X^{2}=12.95, p=0.01\right)$. The lower the rating the respondents attribute to them, the greater the percentage of those who say they consider working abroad.

Although there is no association between the possibility of mobility and the gender of the students, it was found that - contrary to the results found by Cairns (2017), in which only $35 \%$ of Portuguese students say they want to leave the country - the majority $(69.6 \%)$ of our respondents consider this possibility, which is observed for both girls $(66.8 \%)$ and boys (73.2\%). In Cairns's study (2017: 342), female students are the ones who most consider international mobility ( $57 \%$ versus $43 \%$ ).

The predisposition for international labour mobility, according to the students' ages, is higher in the younger students (Table 8). 
Table 8. Labour mobility by age

\begin{tabular}{|c|c|c|}
\hline \multirow{2}{*}{$\begin{array}{c}\text { Age range } \\
\left(\mathbf{X}^{\mathbf{2}}=\mathbf{8 . 7 3} ; \mathbf{p = 0 . 0 0 )}\right.\end{array}$} & Yes & Nossibility of working abroad \\
\cline { 2 - 3 } & $71.7 \%$ & $28.3 \%$ \\
\hline$<25$ years old & $51 \%$ & $49 \%$ \\
\hline$\geq 25$ years old & & 29 \\
\hline
\end{tabular}

(\% by line)

More specifically, those between the ages of 20 and 24 have a more expressive predisposition. According to the Organisation for Economic Co-operation and Development - OECD (2013), this age group suffered the greatest worsening in the unemployment rate between 2007 and 2013 (Table 9).

Table 9. Labour mobility by age group

\begin{tabular}{|l|c|c|}
\hline \multirow{2}{*}{$\begin{array}{c}\text { Age range } \\
\left(\mathbf{X}^{2}=\mathbf{9 . 8 0} ; \mathbf{p = 0 . 0 2 )}\right.\end{array}$} & \multicolumn{2}{c|}{ Possibility of working abroad } \\
\cline { 2 - 3 } & Yes & No \\
\hline$<20$ years old & $69.7 \%$ & $30.3 \%$ \\
\hline $20-24$ years old & $74.8 \%$ & $25.2 \%$ \\
\hline $25-29$ years old & $51.9 \%$ & $48.1 \%$ \\
\hline$>29$ years old & $50 \%$ & $50 \%$ \\
\hline ( $\%$ by line $)$
\end{tabular}

Although in all courses most students indicate that they consider working abroad, the application of the Chi-square test indicates that these variables are not independent. Even though the association between them is weak (Cramer's $V=0.23$ ), it can be concluded that Management students have a lower predisposition for an international work experience, since they are the ones who register a less expressive majority (Table 10). This situation may not be unrelated to the fact that this is the course of the ESGHT, that has the lowest level of unemployment $(5.5 \%)$, according to data from the Directorate-General of Education and Science (2016).

Table 10. Job mobility per course

\begin{tabular}{|c|c|c|}
\hline \multirow{2}{*}{$\begin{array}{c}\text { Course } \\
\left(X^{2}=22.30 ; p=0.00\right)\end{array}$} & \multicolumn{2}{|c|}{ Possibility of working abroad } \\
\hline & Yes & No \\
\hline Management & $56.7 \%$ & $43.3 \%$ \\
\hline Tourism & $80.2 \%$ & $19.8 \%$ \\
\hline Marketing & $64.8 \%$ & $35.2 \%$ \\
\hline Hotel Management & $79.5 \%$ & $20.5 \%$ \\
\hline
\end{tabular}

Both for these courses and all the students surveyed, the preferential countries are the United Kingdom (32.8\%), the United States (12.3\%) and Germany (10.6\%), countries not so strongly affected by the economic crisis of 2008 - similar to what Cairns (2017: 344) observed. Compared to these countries and according to the typology presented by 
Hemming, Schlimbach, Tilmann, Nienaber, Roman and Skrobanek (2019: 49), Portugal is classified as a "beneficiary of mobility", presenting a reduced capacity to produce human capital ${ }^{6}$ but largely benefiting from the development of this capital in young people who experience mobility.

Confronting the results with those reported by Cairns (2017: 343), it was found that our respondents, when asked about the country of preferential destination, seem to give less importance to the fact that English is spoken there (54.0\%), a much inferior value than what the author indicated (87\%).

One of the questions in the questionnaire required students to freely associate a word with the word "emigration". All the words indicated by the students are positive: "opportunity" (22.6\%), "work" (8.4\%) and "better life" (8.1\%), which can be understood as a sign of an optimistic attitude towards the perspective of leaving Portugal.

From the $128(30.1 \%)$ students who do not consider working abroad, the majority are female $(62.5 \%)$, under 25 years old $(81.3 \%)$, and most of them attend $(47.7 \%)$ the Management course. Concern over recent terrorist attacks is not a relevant factor for this option because the overwhelming majority $(82 \%)$ say that this factor has little or no influence.

When asked about their agreement with the statement "Two years from now the crisis will have ended and the employment situation in Portugal will be better than today", it was found that only $17 \%$ of students believe that the crisis and unemployment situation will be resolved in the near future - a result lower than the $21.6 \%$ obtained by Lobo, Ferreira and Rowland (2015) - for residents in Portugal above 15 years old.

\subsection{Predisposition for international academic mobility}

The area of Migration Studies deals with the analysis of the cross-border circulation of young people who attended or have recently attended higher education. Within this area, there is the field of research on International Student Mobility (ISM), which analyses the displacement of young people, either to study at a foreign university or to undertake an internship outside their country. In general, this mobility is due to European mobility programs such as Erasmus of the European Commission (see Gonzalez, Mesanza \& Mariel, 2011; and Oborune, 2013, for example). Another focus of ISM research is those students who choose to study abroad for longer periods of time than European agency programs allow. In these cases, students rely on the help of their parents and/or the nearest family, or travel on their own, as they often choose to work before studying abroad (see, for example, Altbach \& Knight, 2007; and Smith, Rérat \& Sage, 2014).

According to the International Organisation for Migration (2018) report, students' international academic mobility increased globally from around 3.9 million in 2011 to 4.8 million in 2017.

In this study, the majority $(60.67 \%)$ of the students interviewed consider the possibility of studying abroad, and the same was verified in each of the courses. In spite of the weak association (Cramér's $V=0.16$ ), the Chi-square test indicates, however, that the predisposition to study abroad is not independent from the course. It was verified that

6 Hemming, Schlimbach, Tilmann, Nienaber, Roman and Skrobanek (2019: 46) define human capital as a set of skills that contribute to labour productivity and in which individuals can invest. 
Management students, along with the ones from the highest age group (Table 12), are those who are less likely to have an international student experience (Table 11).

Table 11. Student mobility per course

\begin{tabular}{|l|c|c|}
\hline \multirow{2}{*}{$\begin{array}{c}\text { Courses } \\
\left(\mathbf{X}^{\mathbf{2}}=\mathbf{1 1 . 0 0} ; \mathbf{p = 0 . 0 1 )}\right.\end{array}$} & \multicolumn{2}{c|}{ Possibility of studying abroad } \\
\cline { 2 - 3 } & Yes & No \\
\hline Management & $50.7 \%$ & $49.3 \%$ \\
\hline Tourism & $61.0 \%$ & $39.0 \%$ \\
\hline Marketing & $68.6 \%$ & $31.4 \%$ \\
\hline Hotel Management & $70.1 \%$ & $29.9 \%$ \\
\hline
\end{tabular}

(\% by line)

Table 12. Student mobility by age

\begin{tabular}{|c|c|c|}
\hline \multirow{2}{*}{$\begin{array}{c}\text { Age range } \\
\left(\mathbf{X}^{2}=\mathbf{6 . 1 0} ; \mathbf{p = 0 . 0 1 )}\right.\end{array}$} & \multicolumn{2}{|c|}{ Possibility of studying abroad } \\
\cline { 2 - 3 } & Yes & No \\
\hline$<25$ years old & $63.1 \%$ & $36.9 \%$ \\
\hline$\geq 25$ years old & $45,1 \%$ & $54.9 \%$ \\
\hline
\end{tabular}

(\% by line)

Despite the weak association (Phi $=0.25$ ), the majority $(68.5 \%$ ) of students who consider the possibility of working abroad also consider the possibility of studying abroad (Table 13).

Table 13. Student/Professional mobility

\begin{tabular}{|l|c|c|}
\hline \multirow{2}{*}{$\begin{array}{c}\text { Working abroad } \\
\left(\mathbf{X}^{2}=\mathbf{2 4 . 9 1 ;} \mathbf{p = 0 . 0 0 )}\right.\end{array}$} & \multicolumn{2}{c|}{ Studying abroad } \\
\cline { 2 - 3 } & Yes & No \\
\hline Yes & $68.5 \%$ & $31.5 \%$ \\
\hline No & $42.5 \%$ & $57.5 \%$ \\
\hline
\end{tabular}

(\% by line)

\subsection{International mobility and languages}

With regard to students' self-assessment of their language skills, the majority $(70.5 \%)$ of them have a "good" and "excellent" level only in English; whilst $44.3 \%$ and $3.6 \%$ in Spanish and German respectively (Table 14). 
Table 14. Self-assessment of English, German and Spanish skills

\begin{tabular}{|l|c|c|c|}
\hline \multicolumn{1}{|c|}{ Self-assessment of language skills } & English & German & Spanish \\
\hline Insufficient & $5 \%$ & $78.2 \%$ & $13.8 \%$ \\
\hline Sufficient & $24.5 \%$ & $18.2 \%$ & $41.9 \%$ \\
\hline Good & $48.0 \%$ & $3.6 \%$ & $34.8 \%$ \\
\hline Excellent & $22.5 \%$ & $0.0 \%$ & $9.5 \%$ \\
\hline
\end{tabular}

(\% by column)

Analysing the self-assessments of each language by course, it can be observed, for English and German, an association, although weak, between these two variables (contingency coefficient, respectively, of 0.23 and 0.37 ). In the case of English language, most of the evaluations are "good", with a greater percentage of "good" and "excellent" in the courses of Hotel Management and Tourism (Table 15).

Table 15. Self-assessment of English skills by course

\begin{tabular}{|l|c|c|c|c|}
\hline \multirow{2}{*}{ Course } & \multicolumn{4}{|c|}{ Self-assessment of English skills } \\
\cline { 2 - 5 } & Insufficient & Sufficient & \multicolumn{2}{c|}{ Good } \\
\hline Management & $6.3 \%$ & $33.8 \%$ & $47.2 \%$ & $12.7 \%$ \\
\hline Tourism & $6.7 \%$ & $17.6 \%$ & $46.2 \%$ & $29.4 \%$ \\
\hline Marketing & $2.8 \%$ & $25.0 \%$ & $43.1 \%$ & $29.2 \%$ \\
\hline Hotel Management & $2.3 \%$ & $18.2 \%$ & $55.7 \%$ & $23.9 \%$ \\
\hline
\end{tabular}

(\% by line)

There was no "excellent" evaluation for German language, and the majority was classified as insufficient. Once again, it is in the courses mentioned above that the best results were found (Table 16).

Table 16. Self-assessment of German skills by course

\begin{tabular}{|l|r|r|r|}
\hline \multirow{2}{*}{ Course } & \multicolumn{3}{|c|}{ Self-assessment of German skills } \\
\cline { 2 - 4 } & Insufficient & Sufficient & Good \\
\hline Management & $92.1 \%$ & $5.7 \%$ & $2.1 \%$ \\
\hline Tourism & $59.7 \%$ & $31.9 \%$ & $8.4 \%$ \\
\hline Marketing & $95.8 \%$ & $2.8 \%$ & $1.4 \%$ \\
\hline Hotel Management & $67.0 \%$ & $31.8 \%$ & $1.1 \%$ \\
\hline
\end{tabular}

(\% by line) 
Regarding failures in language disciplines, the majority (79.4\%) of the students surveyed, both in global terms (Table 17) and in each of the courses (Table 18), never failed.

Table 17. Failures in Curricular Language Modules

\begin{tabular}{|l|r|}
\hline \multicolumn{2}{|c|}{ Curricular Units of Languages } \\
\hline Never failed & $79.4 \%$ \\
\hline Failed one & $10.6 \%$ \\
\hline Failed twice & $5 \%$ \\
\hline Failed more than twice & $5 \%$ \\
\hline$\%$ by column)
\end{tabular}

Although the association between the course and the number of failures (Coef Contingency $=0.29$ ) is weak, the application of the Chi-square test indicates that the variables are not independent, which leads us to conclude, based on the contingency table below (Table 18), which is in the courses of Tourism and Hotel Management that there is a greater frequency of two or more disapprovals.

Table 18. Failures in Languages by Course

\begin{tabular}{|l|c|c|c|c|}
\hline \multirow{2}{*}{$\begin{array}{c}\text { Course } \\
\left(\mathbf{X}^{2}=\mathbf{1 7 . 7 3} \mathbf{p = 0 . 0 4 )}\right.\end{array}$} & \multicolumn{4}{|c|}{ Situation regarding language disciplines } \\
\cline { 2 - 5 } & Never failed & Failed one & Failed twice & $\begin{array}{c}\text { Failed more than } \\
\text { twice }\end{array}$ \\
\hline Management & $89.9 \%$ & $7.2 \%$ & $1.4 \%$ & $1.4 \%$ \\
\hline Tourism & $74.5 \%$ & $12.7 \%$ & $7.3 \%$ & $5.5 \%$ \\
\hline Marketing & $87.5 \%$ & $9.4 \%$ & $0.0 \%$ & $3.1 \%$ \\
\hline Hotel Management & $62.8 \%$ & $14.0 \%$ & $11.6 \%$ & $11.6 \%$ \\
\hline
\end{tabular}

(\% by line)

The overwhelming majority (91\%) of students declared that they have never taken an English language certification exam. Although this certificate is independent of the course attended $\left(\mathrm{X}^{2}=4.29, \mathrm{p}=0.23\right)$, the percentage of certificate amongst Hotel Management students is higher (Table 19).

Table 19. English Language Certifications

\begin{tabular}{|l|c|c|}
\hline \multirow{2}{*}{ Courses } & \multicolumn{2}{|c|}{ English language certificate } \\
\cline { 2 - 3 } & No & Yes \\
\hline Management & $92.1 \%$ & $7.9 \%$ \\
\hline Tourism & $92.4 \%$ & $7.6 \%$ \\
\hline Marketing & $93.1 \%$ & $6.9 \%$ \\
\hline Hotel Management & $85.4 \%$ & $14.6 \%$ \\
\hline
\end{tabular}

(\% by line) 
When analysing the relationship between the predisposition for international labour mobility and languages, an association, although weak (Phi $=0.18)$, was identified only for the self-assessment of English language. There is a greater predisposition for this experience amongst students who best assessed their knowledge in this language (Table 20).

Table 20. Job mobility / Self-assessment of English

\begin{tabular}{|l|c|c|}
\hline \multirow{2}{*}{$\begin{array}{c}\text { Self-assessment of } \\
\text { English } \begin{array}{c}|2| \\
\mathbf{p}=\mathbf{0 . 0 0})\end{array}\end{array}$} & \multicolumn{2}{|l|}{ Possibility of working abroad } \\
\cline { 2 - 3 } & Yes & No \\
\hline Insufficient-Sufficient & 52.4 & 47.6 \\
\hline Good-Excellent & 76.8 & 23.2 \\
\hline
\end{tabular}

(\% by line)

With respect to international student mobility, there was no association between the predisposition to study abroad and the students' confidence in their language skills for any of the languages considered (English: $X^{2}=4.13, p=0.25$; German: $X^{2}=0.09, p=$ 0.96; Spanish: $X^{2}=1.34, p=0.72$ ).

\section{Conclusions}

The job aspects most valued by the students surveyed, both in global terms and in each of the courses, are "job opportunities" and "possibility of career ladder", followed by "stability and security", and, only in the fourth place, by "remuneration conditions".

The same aspects, when evaluated from the perspective of a professional future in Portugal, present significantly lower values. Amongst them, the most highly rated are "good relationship with colleagues/superiors" and "health and well-being". However, these are not amongst the most important aspects for the respondents.

Although all aspects of the national labour market are worse classified, only the low expectations regarding "stability and security", "remuneration conditions" and "social prestige" influence the predisposition for international labour mobility.

Contrary to the results found by Cairns (2017), the majority $(69.6 \%)$ of the students stated that they considered working abroad, which is observed for both female $(66.8 \%)$ and male $(73.2 \% \%)$. This predisposition is higher in those between the ages of 20 and 24 , precisely the age group that, according to the OECD (2013), experienced the greatest worsening in the unemployment rate between 2007 and 2013. From the preferential destinations, most of them (54\%) are English-speaking, with the UK in first place. It should be remembered this English is the only language with a majority $(70.5 \%)$ of "good" and "excellent" assessments.

The main words associated with the term "emigration" have a positive connotation ("opportunity", "work", "better life"). Taking into account that the words we choose 


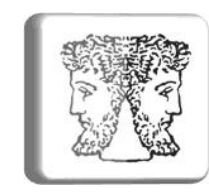

illuminate the view we have of a certain reality, it is possible to conclude that, for the students interviewed, the mobility perspective is fundamentally positive and promising of almost everything a youngster wants when they finish a degree: an opportunity to find a job that gives them a better life.

When questioned about the evolution of employment in Portugal, the same optimism was not manifested. Only $17 \%$ of respondents have a positive perspective for the next two years - a result lower than the $21.6 \%$ obtained by Lobo, Ferreira and Rowland (2015) for residents in Portugal over 15 years old.

For those students who do not consider working abroad $(30.1 \%)$, the concern about the recent terrorist attacks is not a relevant factor, since the overwhelming majority (82\%) said that this is a factor with little or no influence in the decision.

As well as in relation to labour mobility, most of the students $(60.67 \%)$ consider the possibility of studying abroad. Older students ( 25 or over 25 years old) and the ones on the Management course have a lower craving for this kind of student experience. Although weak, there is an association between these two types of mobility. The majority $(68.5 \%)$ of students considering international professional experience also consider the possibility of studying abroad. On the other hand, the predisposition to an international academic experience has no relation to the students' language skills. In relation to labour mobility, this predisposition is greater amongst students who express greater confidence in their English skills.

Even though most of our respondents demonstrate a predisposition for international labour and academic mobility, according to Kmiotek-Meier, Carignani and Vysotskaya (2019: 32), many young Europeans are still reluctant to engage in this type of experience whether for academic or professional purposes. In the European context, mobility can be understood as a tool to overcome inequalities and to guarantee the European Union's social and territorial cohesion objectives (Hemming, Schlimbach, Tilmann, Nienaber, Roman \& Skrobanek, 2019: 45). However, some authors point out that, on the contrary, mobility contributes potentially to the maintenance of inequalities, since individuals who move out are often in a position of disadvantage due, for example, to the devaluation of their academic competences (Bilecen \& Van Mol, 2017: 1246).

In spite of the essentially exploratory and descriptive nature of this study, we believe that it can contribute to a better knowledge of the professional expectations of university students and their perspectives of international mobility.

Given the non-probabilistic nature of the sample used, the study presents limitations regarding the results, which should not be extrapolated outside the context under analysis. The extension of the study to other units of education, and using random sampling, would allow a general interpretation of all Portuguese university students. The second limitation is the use of cross-sectional data, which makes it impossible to analyse the evolution of the variables considered. Given its dynamic nature and the changes that have taken place in the national socio-economic context, it would be interesting to deepen the research from a longitudinal perspective.

This research does however allow us to offer data that can serve as a starting point for studies in which the relationship between the international professional and/or academic mobility and the knowledge/domain of foreign languages is evaluated. 


\section{References}

Aassve, A., Cottini, E. \& Vitali, A. (2013). Youth prospects in a time of economic recession. Demographic Research, 29: 949-962.

Altbach, P. G., \& Knight, J. (2007). The internationalization of higher education: Motivations and realities. Journal of Studies in International Education, 11: 290-305.

Alves, N.A., Cantante, F., Baptista, I. \& Carmo, R.M. (2011). Jovens em transições precárias. Trabalho, quotidiano e futuro. Lisboa: Editora Mundos Sociais / CIES-IUL.

Bell, D.N.F. \& Blanchflower, D.G. (2011). Young people and the Great Recession. Oxford Review of Economic Policy, 27(2): 241-267.

Bilecen, B. \& Van Mol, C. (2017). Introduction: International academic mobility and inequalities. Journal of Ethnic and Migration Studies, 43(8): 1241-1255.

Cairns, D. (2015). International student mobility in crisis? Understanding post-diploma mobility decisionmaking in an economic crisis context. Sociologia, Problemas e Práticas, 79: 9-25.

Cairns, D. (2017). Exploring student mobility and graduate migration: Undergraduate mobility propensities in two economic crisis contexts. Social \& Cultural Geography,18(3): 336-353.

Carmo, R. M., Cantante, F. \& Alves, N.A. (2014). Time projections: Youth and precarious employment. Time \& Society, 23(3): 337-357.

Carmo, R. M. \& Cantante, F. (2014). Desigualdades, redistribuição e o impacto do desemprego: Tendências recentes e efeitos da crise económico-financeira. Sociologia, Problemas e Práticas, 77: 33-51.

Carneiro, A., Portugal, P. \& Varejão, J. (2014). Catastrophic job destruction during the Portuguese conomic crisis. Journal of Macroeconomics, 39: 444-457.

Dietrich, H. (2013). Youth unemployment in the period 2001-2010 and the European crisis: Looking at the empirical evidence. European Review of Labour and Research, 19(3): 305-324.

Engbersen, G. \& Snel, E. (2013). Liquid migration: Dynamic and fluid patterns of postaccession migration flows. In B. Glorius, I. Grabowska-Lusinska e A. Kuvik (Eds.). Mobility in Transition: Migration Patterns after EU Enlargement. Amsterdão: Amsterdam University Press, 21-40.

International Organisation for Migration (2018). Global Mobility Indicators. Berlim: Global Migration Data Analysis Centre [Consultado em fevereiro 2019]. Disponível em https://publications.iom.int/system/files/pdf/global_migration_indicators_2018.pdf

Gonzalez, C. R., Mesanza, R. B. \& Mariel, P. (2011). The determinants of international student mobility flows: An empirical study on the Erasmus programme. Higher Education, 63: 412-430.

Hemming, K., Schlimbach, T., Tilmann, F., Nienaber, B., Roman, M. \& Skrobanek, J. (2019). Structural framework conditions and individual motivations for youth mobility: A macro-micro level approach for different European country-types. Migration Letters, 16(1): 45-59. 
King, R. \& Lulle, A. (2016). Research on Migration: Facing Realities and Maximising Opportunities. Luxemburgo: Publications Office of the European Union.

King, R., Lulle, A., Morosanu, L. \& Williams, A. (2016). International Youth Mobility and Life Transitions in Europe: Questions, Definitions, Typologies and Theoretical Approaches, Working paper 86, University of Sussex, Sussex Centre for Migration Research [Consultado em fevereiro 2019]. Disponível em http://sro.sussex.ac.uk/id/eprint/61441/1/mwp86.pdf

Kmiotek-Meier, E., Carignani, S. \& Vysotskaya, V. (2019). Why is it so hard? And for whom? Obstacles to intra-European mobility. Migration Letters, 16(1): 31-44.

Lobo, M. C., Ferreira, V. S. \& Rowland, J. (2015, 7 de maio). Emprego, mobilidade, política e lazer: Situações e atitudes dos jovens numa perspectiva comparada. [Relatório Apresentado à Presidência da República]. Instituto de Ciências Sociais da Universidade de Lisboa/ OPJ. Observatório Português da Juventude. [Consultado em setembro 2017]. Disponível em http://www.igfse.pt/upload/docs/2015/RoteirosdoFuturo_EstudoJovens2015.pdf

Malheiros, J. (2011). Portugal 2010: O regresso do país de emigração? JANUS.NET: eJournal of International Relations, 2: 133-142.

Oborune, K. (2013). Becoming more European after Erasmus? The impact of the Erasmus programme on political and cultural identity. Epiphany, 6: 182-202.

OCDE (2013). OECD Employment outlook 2013. Paris: OECD Publishing.

Papadopoulos, O. (2014). Youth unemployment discourses in Greece and Ireland before and during the economic crisis: Moving from divergence to 'contingent convergence'. Economic and Industrial Democracy, 37(3): 1-23.

Peixoto, J., Oliveira, I.T., Azevedo, J., Marques, J.C., Góis, P., Malheiros, J. \& Madeira, P.M. (Orgs.) (2016). Regresso ao futuro: A nova emigração e a sociedade portuguesa. Lisboa: Gradiva.

Santos, N. (2016, 8 de fevereiro). Como a emigração está a tramar o PIB. Expresso online. [Consultado em novembro 2017]. Disponível em http://expresso.sapo.pt/blogues/blogue_keynesiano_gracas_a_deus/2016-02-08Como-a-emigracao-esta-a-tramar-o-PIB.

Scarpetta, S., Sonnet, A. \& Manfredi, T. (2010). Rising youth unemployment during the crisis: how to prevent negative long-term consequences on a generation? OECD Social, Employment and Migration Working Papers, 106, Paris, OECD.

Silva, S. M. \& Abrantes, P. (2017). Growing up in Europe's backyard: Researching on education and youth in Portuguese poor suburban settings. In William T. Pink e George W. Noblit (Eds.). Second International Handbook of Urban Education. Londres \& Berlim: Springer, 1335-1349.

Smith, D., Rérat, P., \& Sage, J. (2014). Youth migration and spaces of education. Children's Geographies, 12: 1-8. 